\title{
Curriculum Development and Practice Research of the Course "The Project of Object Oriented Programming”
}

\author{
Wenrong Jiang \\ The school of computer and \\ information, Shanghai second \\ polytechnic University \\ Shanghai, China \\ wrjiang@it.sspu.cn
}

\author{
Min Liu \\ The school of computer and \\ information, Shanghai second \\ polytechnic University \\ Shanghai, China \\ liumin@it.sspu.cn
}

\author{
Jihong Yan \\ The school of computer and \\ information, Shanghai second \\ polytechnic University \\ Shanghai, China \\ jhyan@it.sspu.cn
}

\begin{abstract}
Teaching is an essential part to determine personnel training, teaching quality and teaching level of the university. Curriculum development is an important part of teaching infrastructure. For features and status of "The Project of Object Oriented Programming" and experience of curriculum development, These such as teaching contents, teaching methods, practice teaching and etc were discussed. It promote training students effectively in their engineering capabilities and innovation. It is worth learning for other professional practice curriculum development.
\end{abstract}

Keywords-curriculum development; the project of object oriented programming; practice course; teamwork; schoolenterprise cooperation

\section{INTRODUCTION}

\section{A. The domestic and foreign similar courses}

Object-oriented programming (OOP) is a programming language model.Its organization is directed to "object", instead of "behavior".It is aimed at data, instand of logic.This model is that the object is basic unit of program. It encapsulates the program and data, in order to improve reusability, flexibility and expansibility of software. Therefore, it will strengthen the data analysis thoroughly, reduce development time, and improve the accuracy of the encoding. At present, the objectoriented programming technology has become the mainstream programming model.

\section{B. Basic information of the course}

The project of object-oriented programming is a computerbased undergraduate professional practice course.

Nineteen seventies presents object-oriented technology. At present, many languages include object-oriented features. The technology has been used widely. Among them, because the Java language contains new technologies of 10 years, Java language has many advantages, and in object-oriented programming, it gets attention. This course is intended for application undergraduate. Class timetable is lectures 72 and training three weeks. Class number is more than 40 people/class.

\section{The shortcoming of the course}

This course was taught mainly. Students do a small experimental teaching. Students are lack of comprehensive application ability. For training students' comprehensive application ability is not enough. Now, reform the teaching method of the course, adopt case teaching, improve students' ability.

\section{The goal of the course}

The course pointed out that the course includes teacher, learner, contents and the environment. Curriculum construction must revolve the elements. The teacher is teaching implementation. This is the primary task of curriculum construction to mobilize the teachers' enthusiasm fully, to restructure teachers knowledge structure, to strengthen the education and training, to promote teachers' inherent changes, and gradually to the double teacher transition. Students are teaching carrier, to develop the students' main performance, so that students changes from passive learning to active participation, to cultivate students' lifelong learning ability, to become the multi-skill, solid foundation, the social needs of useful talents. Course content is the main material of teachers teaching, students learning. It is the text information of course construction, to choice materials carefully, to design syllabus reasonablely, to integrate the teaching content, to reform scientificly and systematicly the course program, it can practice students' skills training. With the development of society and the deepening of education reform, to use modern means restructuring information, to absorb a large number of object oriented technology and new achievement, to update and reorganize the course content, that is science and frontier of the course. The environment is the material guarantee for the course construction. Develop to exploit the existing potential for teaching facilities, to strive actively for more facilities, to smooth communication channels of the teachers and students, to establish the standardized teaching new order

it can build a teaching system for people and the environment.

In the "quaternity" course construction idea, extent course teaching to extra-curricular. Through teaching and research of 
the practical course, to strengthen and improve the practical teaching effect. On the basis of professional knowledge, students have good command of object-oriented language, to use skillfully the thought of object-oriented program design, to develop the object-oriented programming projects, and to cultivate good team spirit and high sense of responsibility, they will become high-quality talent including development consciousness and certain ability. This course will be built into the goods practice lesson which has a teaching prominent features, good teaching effect, strong radiation effects highquality.

\section{THE CONTENTS OF THE COURSE CONSTRUCTION}

\section{A. Teacher team}

The teacher team is the important foundation of course construction and teaching reform. In the teacher team, we highlighted the ideas and measures of integration and improvement in order to improve the level of teachers.

- Integration: With the situation and the needs of the development of curriculum, make full use of human resources, will and object oriented course teaching reform of teachers closely related to supply to the curriculum group, enrich the curriculum group of teachers.

- Improve: In curriculum construction, improve the curriculum group of teachers' ideological quality, theoretical knowledge level and teaching and training level, to improve the academic level of the teachers.

Specific implementation measures are:

- To develop the degree. Encourage teachers to enter oneself for an examination the graduate student curriculum group. In recent years, the curriculum group 3 teachers obtain a master's degree, 1 person admitted to the master graduate student, another one teacher admitted to the doctoral students.

- $\quad$ To strengthen exchanges. Curriculum group of teachers in colleges and universities each year teaching research activities. Hire experts to give lectures college. At the same time, the teachers to study abroad, improve the academic and teaching level.

- To take the teacher knowledge update. Provides the opportunity for curriculum group of teachers to take part in all kinds of teacher training, seminars, so as to adapt to the needs of the undergraduate course teaching. In addition, through the mutual listening to lectures, teaching and researching activities to learn from each other, learn from each other to improve the undergraduate course teaching level.

- To participate in academic activities. In recent years, the group of the course teachers create opportunities to participate in the relevant academic activities.

At present, through the introduction and cultivation of the method of combining, the curriculum group of teachers overall level improved, the educational background level increased year by year, the academic level of steadily rising, continuously improve the teaching level to ensure teaching quality has laid a solid foundation.

\section{B. Teaching activity plan}

By the end of semester, organize the class teacher which teaches the next term course, to research and discuss the syllabus, to clear knowledge and teaching requirements, to make sure the new syllabus. During the holidays, for the next semester course, the teacher prepare the course. In the two weeks of semester, the teacher determine the teaching process table, and arrange experiment, organize to attend a lecture, listen to the students' opinions. Weekly, arrange students to ask questions. According to the above situation, the teacher team research and formulate solutions. At split phase of the class, test periodically. Teacher team research and establish the evaluation methods. Before at the end of the semester, on the basis of teaching outline, process table and the teaching actual situation, determine the class form, team cooperation mode, the project schedule and examination form, hire enterprise experts participate in defense. After assessment, assessment course. Every teacher must fill out quality analysis table, analysis teaching and examination situation.

\section{Teaching content construction}

This course is one of professional practice lesson of ecommerce professional. It uses the theory and knowledge of basic course and specialized course. It can train the student to have the problem in analysis, design, develop and maintain the preliminary ability.

\section{Course objective:}

- To cultivate students can start from known problems, to the project carry on comprehensive analysis, refining the corresponding data structure and function module, etc.

- To make the students master the basic object-oriented design theory and method, skillfully using objectoriented various concepts, techniques and skills, learn how to solve the practical work encounter problems, mastery program testing technology, learn to write project documentation, training strain capacity.

- Through the group project training, training the team cooperation spirit and software engineering design specifications.

The teaching contents include:

- $\quad$ The theory part. Lecture: course status, the relationship between before and after the course, and puts forward some problems, and gives the design requirements and schedules.

- The practice part. It is the core of this course, according to the principle of project development, divided into six stages, lets the student through the development of small projects, grasps the objectoriented program development of basic skills, and can flexibly using enterprise JAVA development 
technology to solve some practical problems, master unit and functional testing method, using CVS team cooperation method, the design system.

Key: object oriented analysis and design, system implementation, unit and functional tests

Difficult points: team system realization method

Teaching advice: analysis and design project, the implementation algorithm, carries on the test. The group development, strengthen the team cooperation spirit, defense and evaluation, exercise students strain and project document writing ability.

This course is a door to project development as main technical course. In the course teaching, pay attention to students' experience, and pay attention to teachers' teaching ability training. Cultivate students' teamwork, knowledge, skills, ability, language expression ability, etc. In the curriculum teaching process, pay attention to professional quality education, cultivate the students' excellent quality. According to the specific situation, allocating task and work role, carefully organize the teaching material. In the teaching, according to the students' ability in education, give prominence to the characteristics of project development, detailed explain each technical links and skills to make students master the object oriented theory knowledge, technology, method and project development of the basic methods, steps, test, etc. Through teaching of the course and practice, so that the students with UML design ability, ability to organize project coordination, development, maintenance and test ability, and can use the object-oriented method guidance, for their future engaged in electronic business project development software development projects to provide support.

This by the end of the course, also arrange students to enterprise practice. From the actual project, got the training. By enterprise teacher auxiliary, this has continuous implementation of 2, getting a student's high praise.

\section{Teaching condition construction}

\section{- Use and construction of syllabus, case and materials}

This course choose real enterprise case, designed the experimental instruction, according to the professional and curriculum requirements, make the teaching outline, and connecting with the curriculum and the applied undergraduate teaching characteristic, the project carried out according to the group, according to the enterprise model for teaching, students in practice, knowledge, to enhance the professional skills.

- $\quad$ Practical teaching environment and network teaching environment

Our school has beautiful environment, continuously in recent years by construction and complete the professional laboratory, training building is equipped with many new computer, speed, with high, computer networking, and is equipped with a server and storage equipment, students can complete the project shaers in the storage. Room have projector, facilitate the guidance of teachers and students to demonstrate. Improve assessment method, carries on the overall rating.

\section{- $\quad$ The practice project training}

Relying on and enterprise cooperation, the end of the course, arrange students to enterprises to participate in the project, lets the student in the enterprise to develop the skills. At present, already and a number of enterprises have the cooperation agreement, the student teamwork, control the technology, strengthen the learning motivation and flexible application of knowledge.

\section{E. Construction of teaching methods and teaching means}

- Teaching methods

This course is a experiment, let students understand the requirements, the teacher in the before class, first to teaching class's and grade's previous results to carry on the analysis, the reasonable grouping, lets the student mutual communication, team cooperation and coordination. In the project process, stage assessment, inspires the student through the reasonable method or way to solve the problem, let the students in a workout, improved in project.

\section{- Teaching reform}

In the process of the project, stage test. Project development, submit code and development of technology specifications, and defense, defense teacher must have a enterprise experts. Defense, through the enterprise experts questions, understand the enterprise to the project development requirements and on students' skills, strengthen and the interaction of the enterprise. At the end of the course, before the summer, arrange students to enterprise training, enterprise expert guidance, in the real environment, training students, to develop the skills.

\section{INNOVATION POINT}

- $\quad$ Teaching methods use fully the multimedia courseware, network technology, to play the characteristics of computer courses, to establish the integrated learning system.

- to Train team cooperation spirit, to design the personalized system, to create arouse students enthusiasm for the core of the curriculum design.

- New curriculum content, to follow the trend of The Times. Teachers has related the actual development experience, the teaching experience is also rich, still take to teach a group of young teachers, have a teacher team include the young and middle-aged teachers.

\section{APPLICATION}

Since the course "The Project of Object Oriented Programming" construction, the school educational administration, supervision and our leadership for examination, the result is satisfactory. This course teaching way to get recognized experts. Students through the study, made a lot of work. A great number of students won the interests. After 
graduation, students work in this field, graduated students department manager, project managers winners.

Now this course as a teaching by young teachers, young teachers through their own efforts, progress rapidly, can fully adapt to the students' skill class teaching, by the students' high praise.

\section{CONCLUSION}

Course construction and reform is a long-term and arduous task. In the process of course construction, we should be paid attention to deal with the relations: traditional and the characteristic, the standard and the innovation, contents and methods, basic and professional, teaching and scientific research, the point and surface.
The course "The Project of Object Oriented Programming" construction becomes a good practice teaching course with specialized features, in order to to develop the teacher team, to use the network resources, to improve the teaching level and teaching quality.

\section{REFERENCES}

[1] Liquan Liu, Lei Ding. Curriculum Development Research of Quality Courses and National Quality Courses[J]. University of Education, Science, 2010,No.123(05):34-37 (Ch).

[2] Li Zheng. Solution of Curriculum Development[J]. Computer Education, 2007,No.(11):71-73 (Ch).

[3] Haiyu Song, Xizuo Li, Linfen Wang. Research and Practice the Curriculum Development of Object-oriented Li Zheng. Several Important Relationships of Quality Curriculum Development Experience of the National Quality Course "Object-Oriented Programming"[J]. Computer Education, 2006,No.(10):15-17 (Ch). 